Concord, United States of America; ${ }^{5}$ Sorbonne University, Rheumatology, Paris, France; ${ }^{6}$ AP-HP Saint-Antoine Hospital, Rheumatology, Paris, France; ${ }^{7}$ Inserm, Rheumatology, Paris, France; ${ }^{8}$ St James's Hospital, Rheumatology, Dublin, Ireland; ${ }^{9}$ University of Otago Wellington, Department of Medicine, Wellington, New Zealand; ${ }^{10}$ George Washington University, School of Medicine and Health Sciences, Washington DC, United States of America; ${ }^{11}$ Johns Hopkins University, Rheumatology, Baltimore, United States of America; ${ }^{12}$ Boston University, Rheumatology, Boston, United States of America; ${ }^{13} \mathrm{Hospital}$ for Special Surgery, Department of Medicine, New York, United States of America; ${ }^{14}$ Brigham and Women's Hospital, Rheumatology, Boston, United States of America; ${ }^{15}$ Harvard Medical School, Rheumatology, Boston, United States of America; ${ }^{16}$ HealthPartners \& Regions Hospital, Rheumatology, St. Paul, United States of America; ${ }^{17}$ Universidad Científica del Sur, Rheumatology, Lima, Peru; ${ }^{18}$ Georgetown University, School of Medicine, Washington DC, United States of America; ${ }^{19}$ Massachusetts General Hospital, Division of Rheumatology, Allergy, and Immunology, Boston, United States of America; ${ }^{20}$ University of California San Francisco, Division of Rheumatology, San Francisco, United States of America; ${ }^{21}$ Temple University Lewis Katz School of Medicine, Rheumatology, Philadelphia, United States of America

Background: The COVID-19 pandemic led to a rapid increase in remote consultations in rheumatology care. Due to the potential impact of this change on rheumatology clinical training, we investigated trainees' experiences with telemedicine.

Objectives: To assess the impact of telemedicine use during the COVID-19 pandemic on rheumatology training, including supervision.

Methods: A voluntary, anonymous web-based survey was administered in English, Spanish, or French from 19/08/2020 to 05/10/2020. Adult and paediatric rheumatology trainees worldwide in training in 2020 were invited to participate via social media and email. Using multiple choice questions, Likert scales, and free text answers, we collected data regarding prior and current telemedicine use, training, and supervision.

Results: 302 respondents from 33 countries completed the survey, with most $(83 \%, 252 / 302)$ in adult rheumatology training. Reported use of telemedicine increased from $13 \%(39 / 302)$ pre-pandemic to $82 \%(247 / 302)$ (Table 1). European trainees predominantly utilised audio-only compared to trainees from the rest of the world (ROW) who predominantly utilised audio-video telemedicine. Most trainees continued to evaluate new patients using telemedicine $(65 \%$, $161 / 247)$. A larger proportion of trainees were comfortable using telemedicine to evaluate follow-up (69\% 170/247) versus new patients $(25 \%, 41 / 161)$ (Figure 1). Only $32 \%$ (97/302) were trained in telemedicine, with the highest proportion among United States (US) trainees (59\%, 69/116); subjects included software, clinical skills, and billing. The majority of trainees found this helpful $(92 \%, 89 / 97)$. Supervision was most frequently in the form of verbal discussion after the consultation (Table 1); $24 \%$ (59/247) had no telemedicine supervision during the pandemic. In general, trainees found telemedicine negatively impacted their supervision $(51 \%, 123 / 242)$ and clinical teaching quality $(70 \%, 171 / 244)$; only $9 \%$ reported a positive impact on these areas.

Conclusion: Adoption of telemedicine during the COVID-19 pandemic has led to areas of concern for rheumatology trainees including inadequate supervision and clinical teaching. Our results suggest a need for education on evaluation of new patients using telemedicine, increasing telemedicine training, and ensuring adequate supervisory arrangements.

Table 1. Telemedicine use, supervision, and training by region. Data is presented as $\mathrm{n}(\%)$. Rest of the world (ROW) data includes Asia (50), Central and South America (23), Canada (12), Australia (8), and Africa (4).

\begin{tabular}{|c|c|c|c|c|c|}
\hline & & $\begin{array}{c}\text { Europe } \\
n=89\end{array}$ & $\begin{array}{c}\text { US } \\
\mathrm{n}=116\end{array}$ & $\begin{array}{c}\text { ROW } \\
\mathrm{n}=97\end{array}$ & $\begin{array}{r}\text { Combinec } \\
n=302\end{array}$ \\
\hline \multirow[t]{2}{*}{ Telemedicine use } & Pre-pandemic & $15(17)$ & $9(8)$ & $15(15)$ & $39(13)$ \\
\hline & During pandemic & $64(72)$ & $112(97)$ & $71(73)$ & $247(82)$ \\
\hline \multirow[t]{2}{*}{ Telemedicine modality } & Audio-only & $14(93)$ & $3(33)$ & $8(53)$ & $25(64)$ \\
\hline & Audio-video & $1(7)$ & $7(78)$ & $7(47)$ & $15(38)$ \\
\hline \multicolumn{6}{|l|}{ pre-pandemic } \\
\hline \multirow{2}{*}{$\begin{array}{l}\text { Telemedicine modality } \\
\text { during pandemic }\end{array}$} & Audio-only & $56(88)$ & $47(42)$ & $51(72)$ & $154(62)$ \\
\hline & Audio-video & $7(11)$ & $100(89)$ & $29(41)$ & $136(55)$ \\
\hline Supervision & $\begin{array}{c}\text { Real-time observation (part } \\
\text { of visit) }\end{array}$ & $0(0)$ & $4(44)$ & $3(20)$ & $7(18)$ \\
\hline \multirow[t]{4}{*}{ pre-pandemic } & $\begin{array}{l}\text { Real-time observation (full } \\
\text { visit) }\end{array}$ & $0(0)$ & $2(22)$ & $2(13)$ & $4(10)$ \\
\hline & Verbal discussion after & $8(53)$ & $3(33)$ & $7(47)$ & $18(46)$ \\
\hline & Written communication after & $0(0)$ & $0(0)$ & $1(7)$ & $1(3)$ \\
\hline & None & $7(47)$ & $2(22)$ & $5(33)$ & $14(36)$ \\
\hline \multirow[t]{5}{*}{$\begin{array}{l}\text { Supervision during } \\
\text { pandemic }\end{array}$} & $\begin{array}{c}\text { Real-time observation (part } \\
\text { of visit) }\end{array}$ & $2(3)$ & $54(48)$ & $15(21)$ & $71(29)$ \\
\hline & $\begin{array}{l}\text { Real-time observation (full } \\
\text { visit) }\end{array}$ & $3(5)$ & $32(29)$ & $8(11)$ & $43(17)$ \\
\hline & Verbal discussion after & $32(50)$ & $65(58)$ & $28(39)$ & $125(51)$ \\
\hline & Written communication after & $7(11)$ & $15(13)$ & $9(13)$ & 31 (13) \\
\hline & None & $28(44)$ & $9(8)$ & $22(31)$ & $59(24)$ \\
\hline
\end{tabular}
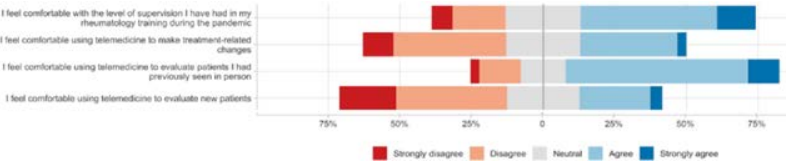

Figure 1. Rheumatology trainee comfort levels in using telemedicine during the pandemic.

Disclosure of Interests: Su-Ann Yeoh: None declared, Kristen Young: None declared, Michael Putman: None declared, Elizabeth Graef: None declared, Francis Berenbaum: None declared, Richard Conway: None declared, Rebecca Grainger Speakers bureau: Speaker fees from Abbvie, Janssen, Novartis, Pfizer, Cornerstones, all not related to this work, Consultant of: Consultancy fees from Abbvie, Janssen, Novartis, Pfizer, Cornerstones, all not related to this work Grant/research support from: Travel assistance from Pfizer, not related to this work, Adam Kilian: None declared, Maximilian Konig: None declared, Jean Liew Grant/research support from: Research grant from Pfizer unrelated to this manuscript, Pedro M Machado Speakers bureau: Speaker fees from Abbvie, BMS, Celgene, Eli Lilly, Janssen, MSD, Novartis, Orphazyme, Pfizer, Roche and UCB all unrelated to this manuscript, Consultant of: Consulting fees from Abbvie, BMS, Celgene, Eli Lilly, Janssen, MSD, Novartis, Orphazyme, Pfizer, Roche and UCB, all unrelated to this manuscript, Sebastian E. Sattui: None declared, Jeffrey Sparks Consultant of: Consultancy for Bristol-Myers Squibb, Gilead, Inova Diagnostics, Optum, and Pfizer unrelated to this manuscript, Grant/research support from: Research support from Bristol-Myers Squibb unrelated to this manuscript, Paul Sufka: None declared, Manuel Ugarte-Gil Grant/research support from: Research grants from Janssen and Pfizer unrelated to this manuscript, Laura Upton: None declared, Zachary Wallace: None declared, Jinoos Yazdany Consultant of: Consultancy for Astra Zeneca, Eli Lilly, and Pfizer, not related to this work, Grant/research support from: Research grants from Gilead and Pfizer, not related to this work, Arundathi Jayatilleke: None declared

DOI: 10.1136/annrheumdis-2021-eular.2205

\section{AB0675 1 COUNTRY COMPARISON ON THE IMPACT OF THE COVID-19 PANDEMIC ON PATIENTS WITH RHEUMATIC DISEASES. RESULTS FROM THE REUMAVID STUDY (PHASE 1)}

M. Garrido-Cumbrera ${ }^{1}$, H. Marzo-Ortega ${ }^{2,3}$, L. Christen ${ }^{4}$, L. Carmona ${ }^{5}$, J. Correa-Fernández ${ }^{1}$, S. Sanz-Gómez ${ }^{1}$, E. Mateus ${ }^{6,7}$, S. Makri ${ }^{8}$, P. PlazueloRamos $^{9}$, L. Grange ${ }^{10,11}$, S. Mingolla ${ }^{12}$, K. Antonopoulou ${ }^{13}$, D. Webb ${ }^{14}$, C. Jacklin ${ }^{15}, \mathrm{~S}$. Irwin ${ }^{16}$, V. Navarro-Compán ${ }^{17}$ on behalf of REUMAVID working group. ${ }^{1}$ Universidad de Sevilla, Health \& Territory Research (HTR), Seville, Spain; ${ }^{2}$ University of Leeds, Leeds Institute for Rheumatic and Musculoskeletal Medicine, Leeds, United Kingdom; ${ }^{3}$ Leeds Teaching Hospitals Trust, NIHR Leeds Biomedical Research Centre, Leeds, United Kingdom; ${ }^{4}$ Novartis Pharma AG, Patient Engagement, Basel, Switzerland; ${ }^{5}$ Institute for Musculoskeletal Health, InMusc, Madrid, Spain; ${ }^{6}$ Liga Portuguesa Contra as Doenças Reumáticas (LPCDR), Management, Lisbon, United Kingdom; ${ }^{7}$ NOVA Medical School, Comprehensive Health Research Centre (CHRC), Lisbon, Portugal; ${ }^{8}$ Cyprus League Against Rheumatism (CYPLAR), Management, Nicosia, Cyprus; ${ }^{9}$ Spanish Federation of Spondyloarthritis Associations (CEADE), Presidency, Madrid, Spain; ${ }^{10}$ French League Against Rheumatism (AFLAR), Management, Grenoble, France; ${ }^{11}$ Centre Hospitalier Universitaire de Grenoble, Rheumatology, Grenoble, France; ${ }^{12}$ Italian National Association of People with Rheumatic and Rare Diseases (APMARR), Communication, Bari, Italy; ${ }^{13}$ Hellenic League Againts Rheumatism (ELEANA), Management, Athens, Greece; ${ }^{14}$ National Axial Spondyloarthritis Society (NASS), Management Department, London, United Kingdom; ${ }^{15}$ National Rheumatoid Arthritis Society (NRAS), Management Department, London, United Kingdom; ${ }^{16}$ Arthritis Action, Management, London, United Kingdom; ${ }^{17}$ Hospital Universitario La Paz, IdiPaz, Madrid, Spain

Background: The COVID-19 pandemic has impacted every aspect of life of European patients with rheumatic and musculoskeletal diseases (RMDs).

Objectives: The aim is to evaluate country differences on the impact of the first wave of the COVID-19 pandemic on life habits, healthcare access, health status, mental health and wellbeing in European patients with RMDs.

Methods: REUMAVID is an international collaboration led by the Health \& Territory Research group at the University of Seville, together with a multidisciplinary team including patient organisations and rheumatologists. This cross-sectional study consisting of an online survey gathering data from patients with a diagnosis of 15 RMDs in Cyprus, France, Greece, Italy, Portugal, Spain, and the United Kingdom. Participants were recruited by patient organisations (April-July 2020). The Kruskal-Wallis and $\chi^{2}$ tests were used to analyse differences between countries and independent variables.

Results: 1,800 patients participated in the first wave of the COVID-19 pandemic (REUMAVID). $37.8 \%$ of Spanish patients increased their smoking consumption 
during the pandemic followed by Cyprus $(32.1 \%)$ and Portugal $(31.0 \%)$, while alcohol consumption was higher in the UK (36.3\%) and France (27.0\%). 82.3\% of patients in Spain unable to attend their appointment with their rheumatologist, either due to cancellations or other personal reasons. Access to primary care was most limited in Portugal and Italy, where only $45.0 \%$ and $51.6 \%$ got access. $61.9 \%$ in Italy and $53.3 \%$ in Spain experienced a worsening of their health during the pandemic. $68.5 \%$ in Spain and $67.8 \%$ in Portugal were at risk of anxiety. The highest proportion at risk of depression was found in Greece (55.4\%), Cyprus $(55.1 \%)$, and Italy (54.8\%). $66.9 \%$ of patients in Spain reported poor wellbeing compared to $23.8 \%$ in Italy and $30.1 \%$ in Portugal (Table 1 ).

Conclusion: The first wave of the pandemic and the related containment measures heterogeneously affected patients with RMDs across European countries, who overall increased harmful habits, experienced more difficulties in accessing healthcare and, reported poor mental health and well-being.

Table 1. Bivariate analysis between European countries $(\mathrm{N}=1,800$, unless specified)

Mean \pm SD or $n(\%)$

\begin{tabular}{|c|c|c|c|c|c|c|c|}
\hline & \multicolumn{7}{|c|}{ Mean \pm SD or $n(\%)$} \\
\hline & $\begin{array}{c}\text { UK } \\
\mathrm{n}: 558\end{array}$ & $\begin{array}{l}\text { Spain } \\
\mathrm{n}: 464\end{array}$ & $\begin{array}{l}\text { France } \\
\mathrm{n}: 229\end{array}$ & $\begin{array}{l}\text { Greece } \\
\mathrm{n}: 57\end{array}$ & $\begin{array}{l}\text { Cyprus } \\
\text { n: } 101\end{array}$ & $\begin{array}{l}\text { Italy } \\
\mathrm{n}: 127\end{array}$ & $\begin{array}{l}\text { Portugal } \\
\text { n: } 264\end{array}$ \\
\hline - Inflammatory arthritis ${ }^{1}$ & $\begin{array}{c}509 \\
(91.2)\end{array}$ & $\begin{array}{c}402 \\
(86.6)\end{array}$ & $\begin{array}{c}147 \\
(64.2)\end{array}$ & 33 (57.9) & $57(56.4)$ & $\begin{array}{c}89 \\
(70.1)\end{array}$ & $\begin{array}{c}120 \\
(45.5)\end{array}$ \\
\hline - Fibromyalgia & $53(9.5)$ & $14(3.0)$ & $26(11.4)$ & $14(24.6)$ & $28(27.7)$ & $\begin{array}{c}53 \\
(41.7)\end{array}$ & $\begin{array}{c}124 \\
(47.0)\end{array}$ \\
\hline - Connective tissue disease ${ }^{2}$ & $36(6.5)$ & $15(3.2)$ & $13(5.7)$ & $25(43.9)$ & $33(32.7)$ & $\begin{array}{c}30 \\
(23.6)\end{array}$ & $61(23.1)$ \\
\hline - Osteoarthritis & $\begin{array}{c}140 \\
(25.1)\end{array}$ & $29(6.3)$ & $\begin{array}{c}102 \\
(44.5)\end{array}$ & $0(0.0)$ & $8(7.9)$ & $15(11.8)$ & 3) $13(4.9)$ \\
\hline - Osteoporosis & $50(9.0)$ & $3(0.6)$ & $20(8.7)$ & $2(3.5)$ & $9(8.9)$ & $\begin{array}{c}18 \\
(14.2)\end{array}$ & $12(4.5)$ \\
\hline $\begin{array}{l}\text { - Vasculitis }{ }^{3} \\
\text { - Sapho (only France) }\end{array}$ & $9(1.6)$ & $1(0.2)$ & $\begin{array}{c}6(2.6) \\
15(6.6)\end{array}$ & $3(5.3)$ & $3(3.0)$ & $5(3.9)$ & $9(3.4)$ \\
\hline Smoking, More than before. & $\begin{array}{c}16 \\
(10.3)\end{array}$ & $\begin{array}{c}48 \\
(37.8)\end{array}$ & $22(24.7)$ & $8(23.5)$ & $9(32.1)$ & $8(20.5)$ & $26(31.0)$ \\
\hline$N=556$ & & & & & & & \\
\hline $\begin{array}{l}\text { Alcohol consumption, More } \\
\text { than before. } N=1,085\end{array}$ & $\begin{array}{c}99 \\
(36.3)\end{array}$ & $\begin{array}{c}48 \\
(10.3)\end{array}$ & $27(27.0)$ & $4(7.0)$ & $4(4.0)$ & $4(13.3)$ & 11 (18.3) \\
\hline $\begin{array}{l}\text { Unable to meet rheumatolo- } \\
\text { gist. } \mathrm{N}=722\end{array}$ & $\begin{array}{c}83 \\
(48.8)\end{array}$ & $\begin{array}{c}186 \\
(82.3)\end{array}$ & $27(30.3)$ & $18(64.3)$ & $22(51.2)$ & $9(31.0)$ & $77(56.2)$ \\
\hline $\begin{array}{l}\text { Access to primary care. } \\
\qquad N=689\end{array}$ & $\begin{array}{c}87 \\
(76.3)\end{array}$ & $\begin{array}{l}65 \\
(67.7)\end{array}$ & $32(76.2)$ & $14(60.9)$ & $17(60.7)$ & $\begin{array}{c}65 \\
(51.6)\end{array}$ & $\begin{array}{c}117 \\
(45.0)\end{array}$ \\
\hline $\begin{array}{l}\text { Change in health status, } \\
\text { Much worse or worse. } \\
\mathrm{N}=1,786\end{array}$ & $\begin{array}{c}214 \\
(38.4)\end{array}$ & $\begin{array}{c}245 \\
(53.3)\end{array}$ & $98(43.0)$ & $24(42.9)$ & ) $38(38.4)$ & $\begin{array}{c}78 \\
(61.9)\end{array}$ & $\begin{array}{c}135 \\
(51.9)\end{array}$ \\
\hline $\begin{array}{l}\text { WHO-5. Poor well-being } \\
(\leq 50) \text {. }\end{array}$ & $\begin{array}{c}292 \\
(52.5)\end{array}$ & $\begin{array}{c}303 \\
(66.9)\end{array}$ & $\begin{array}{c}100 \\
(43.9)\end{array}$ & $21(37.5)$ & $46(46.5)$ & $\begin{array}{c}30 \\
(23.8)\end{array}$ & $78(30.1$ \\
\hline $\mathrm{N}=1,777$ & & & & & & & \\
\hline Risk of anxiety. $\mathrm{N}=1,769$ & $\begin{array}{c}241 \\
(43.6)\end{array}$ & $\begin{array}{l}309 \\
(68.5)\end{array}$ & $\begin{array}{c}118 \\
(52.0)\end{array}$ & $31(55.4)$ & ) $61(62.2)$ & $\begin{array}{c}78 \\
(61.9)\end{array}$ & $\begin{array}{c}175 \\
(67.8)\end{array}$ \\
\hline $\begin{array}{l}\text { Risk of depression. } \mathrm{N}= \\
\quad 1,769\end{array}$ & $\begin{array}{c}186 \\
(33.6)\end{array}$ & $\begin{array}{c}232 \\
(51.4)\end{array}$ & $\begin{array}{c}101 \\
(44.5)\end{array}$ & $31(55.4)$ & $54(55.1)$ & $\begin{array}{c}69 \\
(54.8)\end{array}$ & $\begin{array}{c}138 \\
(53.8)\end{array}$ \\
\hline
\end{tabular}

Note: all relations were significant at the 0.001 level. ${ }^{1}$ Including: Axial Spondyloarthritis, Rheumatoid Arthritis, Psoriatic Arthritis, Juvenile Idiopathic Arthritis, Gout and Peripheral Spondyloarthritis; ${ }^{2}$ Including: Systemic Lupus Erythematosus, Sjögren's Syndrome, Systemic Sclerosis and Myositis; ${ }^{3}$ Including: Polymyalgia Rheumatic and Vasculitis or Arteritis.

Acknowledgements: This study was supported by Novartis Pharma AG. We would like to thank all patients that completed the survey as well as all of the patient organisations that participated in the REUMAVID study including: the Cyprus League Against Rheumatism (CYPLAR) from Cyprus, the Association Française de Lutte Anti-Rhumatismale (AFLAR) from France, the Hellenic League Against Rheumatism (ELEANA) from Greece, the Associazione Nazionale Persone con Malattie Reumatologiche e Rare (APMARR) from Italy, the Portuguese League Against Rheumatic Diseases (LPCDR), from Portugal, the Spanish Federation of Spondyloarthritis Associations (CEADE), the Spanish Patients' Forum (FEP), UNiMiD, Spanish Rheumatology League (LIRE), Andalusian Rheumatology League (LIRA), Catalonia Rheumatology League and Galician Rheumatology League from Spain, and the National Axial Spondyloarthritis Society (NASS), National Rheumatoid Arthritis (NRAS) and Arthritis Action from the United Kingdom.

Disclosure of Interests: Marco Garrido-Cumbrera: None declared, Helena Marzo-Ortega Speakers bureau: AbbVie, Biogen, Celgene, Janssen, Lilly, Novartis, Pfizer, Takeda and UCB, Consultant of: AbbVie, Celgene, Janssen, Lilly, Novartis, Pfizer and UCB, Grant/research support from: Janssen and Novartis, Laura Christen Employee of: Novartis Pharma AG, Loreto Carmona: None declared, José Correa-Fernández: None declared, Sergio Sanz-Gómez: None declared, Elsa Mateus Grant/research support from: Lilly Portugal, Sanofi, AbbVie, Novartis, Grünenthal S.A., MSD, Celgene, Medac, Janssen-Cilag, Pharmakern, GAfPA., Souzi Makri Grant/research support from: Novartis, GSK and Bayer.,
Pedro Plazuelo-Ramos: None declared, LAURENT GRANGE: None declared, Serena Mingolla: None declared, KATY ANTONOPOULOU: None declared Dale Webb Grant/research support from: AbbVie, Biogen, Janssen, Lilly, Novartis and UCB, Clare Jacklin Grant/research support from: Abbvie, Amgen, Biogen, Eli Lilly, Gilead, Janssen, Pfizer, Roche, Sanofi \& UCB, Shantel Irwin: None declared, Victoria Navarro-Compán Grant/research support from: Abbvie, BMS, Lilly, MSD, Novartis, Pfizer, Roche, and UCB

DOI: 10.1136/annrheumdis-2021-eular.2372

\section{$\mathrm{AB} 0676$ \\ FEARS AND HOPES DURING THE COVID-19 PANDEMIC IN PATIENTS WITH RHEUMATIC DISEASES RESULTS FROM THE REUMAVID STUDY (PHASE 1)}

M. Garrido-Cumbrera ${ }^{1}$, H. Marzo-Ortega ${ }^{2,3}$, L. Christen ${ }^{4}$, L. Carmona ${ }^{5}$, J. Correa-Fernández ${ }^{1}$, S. Sanz-Gómez ${ }^{1}$, P. Plazuelo-Ramos ${ }^{6}$, D. Webb ${ }^{7}$ C. Jacklin ${ }^{8}$, S. Irwin ${ }^{9}$, L. Grange ${ }^{10,11}$, S. Makri ${ }^{12}$, E. Mateus ${ }^{13,14}$, S. Mingolla ${ }^{15}$, K. Antonopoulou ${ }^{16}$, V. Navarro-Compán ${ }^{17}$ on behalf of REUMAVID working group. ${ }^{1}$ Universidad de Sevilla, Health \& Territory Research (HTR), Sevilla, Spain; ${ }^{2}$ University of Leeds, Leeds Institute for Rheumatic and Musculoskeletal Medicine, Leeds, United Kingdom; ${ }^{3}$ Leeds Teaching Hospitals Trust, NIHR Leeds Biomedical Research Centre, Leeds, United Kingdom; ${ }^{4}$ Novartis Pharma AG, Patient Engagement, Basel, Switzerland; ${ }^{5}$ Institute for Musculoskeletal Health, InMusc, Madrid, Spain; ${ }^{6}$ Spanish Federation of Spondyloarthritis Associations (CEADE), Presidency, Madrid, Spain; ${ }^{7}$ National Axial Spondyloarthritis Society (NASS), Management, London, United Kingdom; ${ }^{8}$ National Rheumatoid Arthritis Society (NRAS), Management, London, United Kingdom; ${ }^{9}$ Arthritis Action, Management, London, United Kingdom; ${ }^{10}$ French League Against Rheumatism (AFLAR), Management, Grenoble, France; ${ }^{11}$ Centre Hospitalier Universitaire de Grenoble, Management, Grenoble, France; ${ }^{12}$ Cyprus League Against Rheumatism (CYPLAR), Management, Nicosia, Cyprus; ${ }^{13}$ Liga Portuguesa Contra as Doenças Reumáticas (LPCDR), Management, Lisbon, Portugal; ${ }^{14}$ NOVA Medical School, Comprehensive Health Research Centre (CHRC), Lisbon, Portugal; ${ }^{15}$ Italian National Association of People with Rheumatic and Rare Diseases (APMARR), Communication, Bari, Italy; ${ }^{16}$ Hellenic League Againts Rheumatism (ELEANA), Management, Athens, Greece; ${ }^{17}$ Hospital Universitario La Paz, IdiPaz, Madrid, Spain

Background: The first wave of the COVID-19 pandemic led to a rapidly evolving global crisis characterized by major uncertainty.

Objectives: The objective is to assess COVID-19-related fears and hopes in patients with rheumatic and musculoskeletal diseases (RMDs) during the first wave of the pandemic.

Methods: REUMAVID is an international collaboration led by the Health \& Territory Research group at the University of Seville, together with a multidisciplinary team including patient organisations and rheumatologists. This cross-sectiona study consisting of an online survey gathering data from 1,800 patients with a diagnosis of 15 RMDs recruited by patient organisations in Cyprus, France, Greece, Italy, Portugal, Spain and, the United Kingdom. Data are collected in two phases, the first phase between April and July 2020, the second in 2021 Participants rated a series of fears (infection, medication consequences, lack of medication, impact on healthcare, job loss, civil disorder) on a Likert scale from zero ("no concern at all") to five ("extremely concerned") and their hopes (treatment/vaccine availability, going outside, travel, economic situation, treatment continuation, health status) on a Likert scale from zero ("not hopeful at all") to five ("extremely hopeful"). The Mann-Whitney and Kruskal-Wallis tests were used to analyse the different fears and hopes according to socio-demographics characteristics, disease and health status.

Results: 1,800 patients participated in the first phase of REUMAVID. The most frequent RMDs group was inflammatory arthritis $(75.4 \%)$, the mean age was 52.6 years and $80.1 \%$ were female. The most important fear for patients was the impact of the COVID-19 pandemic on healthcare (3.1 out of 5), particularly for those younger in age (3.0 vs $3.2, p=0.004)$, female gender ( 3.2 vs 2.9 of men, $p=0.003$ ), experiencing greater pain ( 3.1 vs $2.8, p=0.007)$, with higher risk of anxiety ( 3.3 vs 2.9 of without anxiety, $p<0.001$ ) and depression ( 3.3 vs 2.9 without depression, $\mathrm{p}<0.001)$. The possible impact of anti-rheumatic medication and the development of severe disease if they became infected with COVID-19,was mostly feared ( 2.8 out of 5), by those receiving biological therapy (3.1 vs 2.5 not biological therapy, $p<0.001)$ or those with underlying anxiety $(2.9$ vs 2.6 without anxiety, $\mathrm{p}=0.007$ ). The risk of contracting COVID-19 due to their condition (2.8 out of 5), was especially feared by those with vasculitis (3.2 out of 5), who were female ( 2.9 vs $2.5, p<0.001$ ), using biologics ( 2.9 vs 2.7 of no use, $p=0.003$ ), in greater pain ( 2.8 vs $2.4, p<0.001)$, with a risk of anxiety (3.0 vs 2.6 without anxiety, $p=0.004$ ), and risk of depression ( 3.0 vs 2.6 without depression, $p<0.001$ ) The major hopes were to be able to continue with their treatment as usual (3.7 out of 5), particularly for those taking biologics ( 3.8 vs 3.6 not taking, $p=0.026$ ), those with a better well-being ( 3.8 vs 3.6 with worse well-being, $p=0.021$ ), without anxiety (3.8 vs 3.6 at risk, $p=0.004$ ) and without depression (3.8 vs 3.6 at risk 